\title{
Protection Afforded by Fluoroquinolones in Animal Models of Respiratory Infections with Bacillus anthracis, Yersinia pestis, and Francisella tularensis
}

\author{
Johnny W. Peterson ${ }^{1, *}$, Scott T. Moen ${ }^{2}$, Daniel Healy ${ }^{3}$, Jennifer E. Pawlik ${ }^{4}$, Joanna Taormina ${ }^{5}$, \\ Jason Hardcastle $^{6}$, John M. Thomas ${ }^{7}$, William S. Lawrence ${ }^{8}$, Cindy Ponce ${ }^{9}$, Bagram M. Chatuev ${ }^{10}$, \\ Bryan T. Gnade ${ }^{11}$, Sheri M. Foltz ${ }^{12}$, Stacy L. Agar ${ }^{13}$, Jian Sha ${ }^{14}$, Gary R. Klimpel ${ }^{15}$, Michelle L. \\ Kirtley $^{16}$, Tonyia Eaves-Pyles ${ }^{17}$ and Ashok K. Chopra ${ }^{18}$
}

\author{
1,2,4-6,8-12,14,16,18 Department of Microbiology and Immunology, Galveston National Laboratory, University of Texas \\ Medical Branch, 301 University Blvd. Galveston, Texas 77555-0610 \\ ${ }^{3}$ James Winkle College of Pharmacy, University of Cincinnati Health Sciences Center, Cincinnati, OH 45267-0004 \\ 7,13,15,17Department of Microbiology and Immunology, University of Texas Medical Branch, 301 University Blvd. \\ Galveston, Texas 77555-0610
}

\begin{abstract}
Successful treatment of inhalation anthrax, pneumonic plague and tularemia can be achieved with fluoroquinolone antibiotics, such as ciprofloxacin and levofloxacin, and initiation of treatment is most effective when administered as soon as possible following exposure. Bacillus anthracis Ames, Yersinia pestis CO92, and Francisella tularensis SCHU S4 have equivalent susceptibility in vitro to ciprofloxacin and levofloxacin (minimal inhibitory concentration is 0.03 $\mu \mathrm{g} / \mathrm{ml}$ ); however, limited information is available regarding in vivo susceptibility of these infectious agents to the fluoroquinolone antibiotics in small animal models. Mice, guinea pig, and rabbit models have been developed to evaluate the protective efficacy of antibiotic therapy against these life-threatening infections. Our results indicated that doses of ciprofloxacin and levofloxacin required to protect mice against inhalation anthrax were approximately 18-fold higher than the doses of levofloxacin required to protect against pneumonic plague and tularemia. Further, the critical period following aerosol exposure of mice to either $B$. anthracis spores or $Y$. pestis was $24 \mathrm{~h}$, while mice challenged with $F$. tularensis could be effectively protected when treatment was delayed for as long as $72 \mathrm{~h}$ postchallenge. In addition, it was apparent that prolonged antibiotic treatment was important in the effective treatment of inhalation anthrax in mice, but short-term treatment of mice with pneumonic plague or tularemia infections were usually successful. These results provide effective antibiotic dosages in mice, guinea pigs, and rabbits and lay the foundation for the development and evaluation of combinational treatment modalities.
\end{abstract}

Keywords: Anthrax, plague, tularemia, ciprofloxacin, levofloxacin, animal models.

\section{INTRODUCTION}

Antibiotics are still considered to be the most effective therapeutic regimen in the treatment of patients with inhalation anthrax, pneumonic plague, and tularemia, although new treatment modalities, for example, with human monoclonal antibodies against protective antigen (PA) of Bacillus anthracis [1-5] and antitoxic drugs [6-8] are being developed, along with new second generation prophylactic vaccines [911]. It is likely that new therapeutics against these infections would be used in combination with effective antibiotics, and knowing dose and blood concentrations in different laboratory animal species would be essential for combinational

*Address correspondence to this author at the Department of Microbiology and Immunology, Galveston National Laboratory, University of Texas Medical Branch, 301 University Blvd. Galveston, Texas 77555-0610, USA; Tel: (409) 266-6917; Fax: (409) 266-6810;

E-mail: johnny.peterson@utmb.edu studies in small animal models. Currently, two antibiotics have been approved by the U.S. Food and Drug Administration for the treatment of inhalation anthrax, ciprofloxacin and levofloxacin. Anthrax also can be effectively treated with other antibiotics including penicillin, tetracycline and streptomycin. Likewise, streptomycin, tetracycline, and gentamicin are antibiotics of choice against plague and tularemia [12-15]. Although currently, there is no available vaccine against plague, a recombinant vaccine containing capsular antigen (F1) and low calcium response antigen V (LcrV) has shown promising results in mouse and non-human primate models [16, 17]. Likewise, a live attenuated vaccine strain (LVS) of $F$. tularensis is approved for vaccination of military personnel and those investigators working with this pathogen [18].

The fluoroquinolones exhibit extensive tissue penetration, concentration-dependent killing and a prolonged postantibiotic effect against susceptible bacteria [19]. Pharma- 
codynamic data from in vitro, large animal, and human studies suggest that fluoroquinolone efficacy is associated with achieving a maximum serum concentration $\left(\mathrm{C}_{\max }\right)$ to minimum inhibitory concentration (MIC) ratio (Cmax/MIC) of $>10$ and area under the 24-hour serum concentration-time curve to MIC ratio (AUC/MIC) of $>125$ for most gramnegative bacteria [19-21]. For most gram-positive organisms, a lower 24-hour AUC/MIC ratio of $>25$ is required for optimal bacterial eradication [22]. Published pharmacodynamic data involving fluoroquinolones against $B$. anthracis [23-25] $Y$. pestis [26-28], or $F$. tularensis [29-31] are mostly limited to murine models; however, fluoroquinolone data against anthrax derived from in vitro modeling studies [32, 33] and nonhuman primate models [34-36] have been reported.

From a recent study conducted by Ambrose and colleagues [23] evaluating gatifloxacin in a murine model of $B$. anthracis inhalation infection, it was shown that the $\mathrm{AUC}_{24} / \mathrm{MIC}$ ratio is the pharmacodynamic parameter that best predicts outcome with $90 \%$ and $99 \%$ effective doses corresponding to $\mathrm{AUC}_{24} / \mathrm{MIC}$ ratios of 15.8 and 30, respectively. These degrees of fluoroquinolone exposure that predict a desirable outcome in mice correspond to a $\mathrm{AUC}_{24} / \mathrm{MIC}$ ratio of about 200-300 in humans [37]. Among the few studies of fluoroquinolone administration in the guinea pig and rabbit models of inhalation anthrax are reports by Altboum et al. [38], Shoop et al. [39], and Peterson et al. [4]. Since these are important small animal models for development of new treatment modalities against anthrax, plague, and tularemia, the current findings provide important information on dosing and blood levels of the fluoroquinolones useful in the development of adjunctive therapies [37, 40, 41].

In addition to their direct antimicrobial effects, it is well recognized that fluoroquinolones possess potent concentration-dependent immunomodulatory properties [42]. In particular, they have been shown to protect mice from lipopolysaccharide (LPS)-induced death, presumably by decreasing the production/secretion of proinflammatory mediators such as tumor necrosis factor-alpha (TNF- $\alpha$ ), interleukins (IL)-1 $\alpha / \beta,-6,-8$ and $-12[43,44]$. Further, enhancement of hematopoietic stimulating factors such as IL-2, IL-33 and pulmonary production of granulocyte-macrophage colony stimulating factor (GM-CSF) has been associated with fluoroquinolone treatment in various animal models [45, 46]. The underlying mechanisms of these immunomodulatory properties are not well defined, but may involve their effects on signal transduction, intracellular transcription factors, and/or interactions with the type II topoisomerase complex [42].

In this report, we chose the nasal instillation models of inhalation anthrax with Swiss-Webster mice, Hartley guinea pigs, and Dutch-belted rabbits to evaluate the protection afforded by ciprofloxacin and levofloxacin. Similarly, we evaluated the effectiveness of levofloxacin against pneumonic plague and tularemia using murine models. For the latter two diseases, we preferred to use only levofloxacin as our studies with anthrax indicated that it was as efficacious or better than ciprofloxacin and could be given to animals only once per day compared to ciprofloxacin that needed to be given to animals twice because of its shorter half life. Pharmacokinetic studies in all three animal models were designed to provide information about the blood levels of both antibiotics in the animals challenged with these patho- gens. The results may be beneficial as a guide to health authorities in selecting antibiotic dose levels for patients in the event of future acts of bioterrorism involving these select agents.

\section{MATERIALS AND METHODOLOGY}

\section{Antibiotics}

Sterile, injectable formulations of ciprofloxacin (Bayer Pharmaceuticals Corp., West Haven, CT) and levofloxacin (Janssen Pharmaceutica, N.V., Beerse, Belgium) were purchased from the UTMB Pharmacy. Although normally infused intravenously into patients as 5\% levofloxacin and $0.2 \%$ ciprofloxacin in $5 \%$ dextrose solution, respectively, animals in this study were injected with the antibiotics by the subcutaneous or intraperitoneal routes in the amounts indicated in the Results section.

\section{MIC of Ciprofloxacin and Levofloxacin Against $B$. anthracis, $Y$. pestis, and $F$. tularenesis}

The MIC of ciprofloxacin and levofloxacin against various pathogens was determined by using the E-Test (AB Biodisk North America Inc, Culver City, CA) [47]. Briefly, the overnight-grown bacterial cultures were diluted (1:4) with fresh Luria-Bertani (LB) medium and continued to grow at $28^{\circ} \mathrm{C}$ for $Y$. pestis $\mathrm{CO} 92$ and $37^{\circ} \mathrm{C}$ for B. anthracies Ames and $F$. tularenesis SCHU S4 for $2 \mathrm{~h}\left(\mathrm{OD}_{600 \mathrm{~nm}}\right.$ of 0.6$)$. The bacterial cultures were then spread evenly onto the MuellerHinton agar plates (Becton Dickinson, Cockeysville, MD) or on 5\% sheep blood agar (SBA) plates (Teknova, Hollister, $\mathrm{CA}$ ), and the predefined levofloxacin (range of 0.002 to 32 $\mu \mathrm{g} / \mathrm{ml})$ E-strips were placed onto the plates. Plates were incubated for $48 \mathrm{~h}$ at either $28^{\circ} \mathrm{C}$ or $37^{\circ} \mathrm{C}$, and the MIC values were recorded.

\section{Preparation of $B$. anthracis spores}

Spores were prepared by inoculating B. anthracis Ames strain in Schaeffer's sporulation medium [48] as we previously described [7]. We confirmed sporulation to be at $>99 \%$ via phase contrast microscopy and the Wirtz spore stain [49]. Aliquots of the stock spore suspension $\left(1 \times 10^{9}\right.$ to $1 \times 10^{10}$ $\mathrm{cfu} / \mathrm{ml}$ ) were stored at $-70^{\circ} \mathrm{C}$, and freshly diluted in phosphate-buffered saline (PBS) to the desired colony forming units (cfu) immediately before each animal challenge experiment.

\section{Preparation of $Y$. pestis $\mathrm{CO} 92$ culture}

Virulent $Y$. pestis strain CO92 was obtained from the Centers for Disease Control and Prevention (CDC), Atlanta, GA. To prepare $Y$. pestis cultures, we followed our recently described protocol $[50,51]$.

B. anthracis cultures and spores as well as $Y$. pestis cultures were prepared and stored in a restricted access BSL-2 laboratory registered with the $\mathrm{CDC}$ and inspected by the Department of Defense and the United States Department of Agriculture.

\section{Preparation of $\boldsymbol{F}$. tularenesis SCHU S4 culture}

An aliquot of stock was plated on cysteine heart infusion agar (Difco Laboratories, Detroit, MI) plates for 2 days at 
$37^{\circ} \mathrm{C}$ with $5 \% \mathrm{CO}_{2}$. Bacterial colonies were expanded in modified Mueller-Hinton II broth supplemented with IsoVitaleX (Becton Dickinson, Cockeysville, MD) for $10 \mathrm{~h}$ with shaking at $37^{\circ} \mathrm{C}$. After centrifugation, bacterial pellets were resuspended in PBS, the cell number determined with a Petroff-Hausser cell counting chamber (Hausser Scientific, Horsham, PA), and adjusted to the desired concentrations by diluting in PBS [52]. F. tularenesis culture was stored and cultivated in the CDC approved BSL-3 laboratory.

\section{Challenge of Mice, Guinea Pigs, and Rabbits Via the Intranasal Route}

To evaluate the protective efficacy of ciprofloxacin and levofloxacin in vivo, we challenged 8-week-old (25 to 30-g) female Swiss-Webster mice (Taconic, Germantown, NY) and 250 to 300-g Hartley guinea pigs (Charles River Laboratories, Wilmington, MA) with $5 \times 10^{4} \mathrm{cfu}$ and $6 \times 10^{5} \mathrm{cfu}$ of B. anthracis Ames spores, respectively. Swiss-Webster mice were also challenged with $5 \operatorname{LD}_{50}\left(1.7 \times 10^{3}\right)$ of $Y$. pestis CO92. BALB/c mice were challenged with $3 \mathrm{LD}_{50}\left(1.7 \times 10^{2}\right.$ $\mathrm{cfu}$ ) doses of $F$. tularensis SCHU S4. Dutch-belted rabbits (0.7-1.1 kg; Myrtle's Rabbitry, Inc., Thompson Station, TN) were challenged with $100 \mathrm{LD}_{50}$ 's $\left(1 \times 10^{7} \mathrm{cfu}\right)$ of $B$. anthracis Ames spores.

Mice and guinea pigs were anesthetized by intraperitoneal (i.p.) and subcutaneous (s.c.) routes, respectively, with a mixture of ketamine- $\mathrm{HCl}(48 \mathrm{mg} / \mathrm{kg}$ for mice and $30 \mathrm{mg} / \mathrm{kg}$ for guinea pigs) and xylazine- $\mathrm{HCl}(9.6 \mathrm{mg} / \mathrm{kg}$ for mice and 7 $\mathrm{mg} / \mathrm{kg}$ for guinea pigs). Rabbits were anesthetized with ketamine $(35 \mathrm{mg} / \mathrm{kg})$ and xylazine $(5 \mathrm{mg} / \mathrm{kg})$ by intramuscular (i.m.) injection. For spore/bacteria instillation in animals, we used the method of Comer et al. [7]. The challenge volume was $20 \mu \mathrm{l} /$ naris for mice, $25 \mu \mathrm{l} /$ naris for guinea pigs, and $50 \mu \mathrm{l} /$ naris for rabbits. PBS $(20,25$, and $50 \mu 1 /$ naris $)$ was then used to wash any non-adherent spores from the nasal cavity into the lungs for each animal species, respectively. All animal challenges were performed in a select agentapproved, restricted-access Animal Biosafety Level 3 Laboratory under approved protocols in accordance with guidelines recommended by the National Institutes of Health, Centers for Disease Control, and United States Department of Agriculture. In the animal studies, antibiotics were given $24 \mathrm{~h}$ post infection or at various delayed time points as indicated for a period of 6-13 days. In mice, the antibiotics were given by the i.p. route, in guinea pigs by the s.c. route, while in rabbits, antibiotics were injected via the i.m. route.

\section{Fluoroquinolone Assay}

All serum specimens were assayed by the reversed-phase high-performance liquid chromatographic (HPLC) method with fluorescence detection as previously described [53-54].

\section{Pharmacokinetic Studies and Analysis}

Studies in mice were performed using a sample size of $\mathrm{n}=4$ at each time point (e.g., 0, 0.25, 1, 1.5, 2, 4, 6, 12, 24, 36 and $48 \mathrm{~h}$ ) following dose administration of ciprofloxacin (90 $\mathrm{mg} / \mathrm{kg}$ [i.p.]) and levofloxacin (5 and $90 \mathrm{mg} / \mathrm{kg}$ [i.p.]). Studies in guinea pigs ( $\mathrm{n}=8$ per regimen: ciprofloxacin $15 \mathrm{mg} / \mathrm{kg}$ [s.c.] and levofloxacin $8.5 \mathrm{mg} / \mathrm{kg}$ [s.c.]) and rabbits $(\mathrm{n}=10$ per regimen: ciprofloxacin $10 \mathrm{mg} / \mathrm{kg}$ [i.m.]; levofloxacin 7.1 $\mathrm{mg} / \mathrm{kg}$ [i.m.]) were conducted, which provided $\mathrm{n}=6$ serum concentrations over the $48 \mathrm{~h}$ time period. The dose of each fluoroquinolone was based on the effective dose for $100 \%$ of the animals $\left(\mathrm{ED}_{100}\right)$ as determined from the survival studies.

The serum concentration-time data were analyzed by standard noncompartmental methods [55]. The maximum concentration $\left(\mathrm{C}_{\max }\right)$ in serum and the time to reach $\mathrm{C}_{\max }$ $\left(\mathrm{T}_{\max }\right)$ were determined directly from the individual concentration data. The terminal elimination rate constant $\left(\lambda_{z}\right)$ was obtained by least-squares regression of the log serum drug concentrations in the log-linear phase. A minimum of three concentration-time points were used to represent the loglinear phase for rabbits and guinea pigs in which each animal provided multiple serum specimens for concentration determination. Composite data were used to assess this parameter in mice. The elimination half-life $\left(\mathrm{t}_{1 / 2}\right)$ was calculated by dividing 0.693 by $\lambda_{z}$. The area under the concentration-time curve for ciprofloxacin and levofloxacin from time zero (predose) to infinity $\left(\mathrm{AUC}_{0-\infty}\right)$ was calculated by the linear trapezoidal rule with extrapolation to infinity, using $C_{t} / \lambda_{z}$, where $C_{t}$ is the last measurable concentration. The apparent total body clearance (TBC) was calculated by the administered dose divided by $\mathrm{AUC}_{0-\infty}$.

\section{Statistics}

All of the animal survival data were analyzed with the Fisher's exact test using the SigmaStat Statistical package (SYSTAT, Richmond, CA). Pharmacokinetic parameters for ciprofloxacin and levofloxacin within species were compared using the Student's t-test unless normality failed in which case the nonparametric Mann-Whitney rank sum test was employed. All statistical tests were performed at the 5\% level of significance. Results were expressed as means \pm standard deviations, with the exception of $\mathrm{T}_{\max }$ values, which were given as the median (range).

\section{RESULTS}

\section{$\mathrm{LD}_{50}$ doses for $B$. anthracis, $Y$. pestis, and $F$. tularensis}

Table 1 lists the $\mathrm{LD}_{50}$ doses of the above-mentioned agents in Swiss-Webster and BALB/c mice. These three bacterial pathogens could be ranked in order of decreasing infectivity based on $\mathrm{LD}_{50}$ dose in a murine model; $F$. $t u$ larensis $>Y$. pestis $>B$. anthracis. Based on these data, we elected to use Swiss-Webster mice for the study of B. anthracis and $Y$. pestis, while the increased sensitivity of BALB/c mice influenced our selection of this species for the study of $F$. tularensis. Also shown are the $\mathrm{LD}_{50}$ values of B. anthracis Ames spores for Hartley guinea pigs and Dutch-belted rabbits.

\section{Ciprofloxacin and Levofloxacin Protect Mice Against Inhalation Exposure to B. anthracis Ames spores}

Fig. (1A) illustrates that administration of ciprofloxacin in doses of $90-120 \mathrm{mg} / \mathrm{kg} /$ day (b.i.d.) was required to achieve complete protection during treatment of SwissWebster mice against challenge with $5 \mathrm{LD}_{50}$ of $B$. anthracis spores, but sustained treatment was essential. The highest dose of $180 \mathrm{mg} / \mathrm{kg} /$ day appeared to reach a toxic level, since survival decreased compared to that of $90-120 \mathrm{mg} / \mathrm{kg} / \mathrm{day}$ doses. Ciprofloxacin doses of $60 \mathrm{mg} / \mathrm{kg} /$ day or below were not protective. Interestingly, even relatively high doses of 
Table 1. Fifty Percent Lethal Dose $\left(\mathrm{LD}_{50}\right)$ of B. anthracis, $Y$. pestis, and F. tularensis in Laboratory Animals Using Nasal Instillation

\begin{tabular}{|l|l|l|l|}
\hline Animal Model & B. anthracis Ames Spores (cfu) & Y.pestis CO92 Cells (cfu) & F. tularensis SCHU S4 Cells (cfu) \\
\hline \hline Swiss-Webster Mice & $1.1 \times 10^{4}$ & $3.4 \times 10^{2}$ & $2.2 \times 10^{2}$ \\
\hline BALB/c Mice & $1.7 \times 10^{4}$ & $1.0 \times 10^{2}$ & $3.3 \times 10^{1}$ \\
\hline Hartley Guinea Pigs & $1.2 \times 10^{5}$ & N.D. & N.D. \\
\hline Dutch-belted Rabbits & $1.0 \times 10^{5}$ & N.D. & N.D. \\
\hline
\end{tabular}

N.D. $=$ Not done.

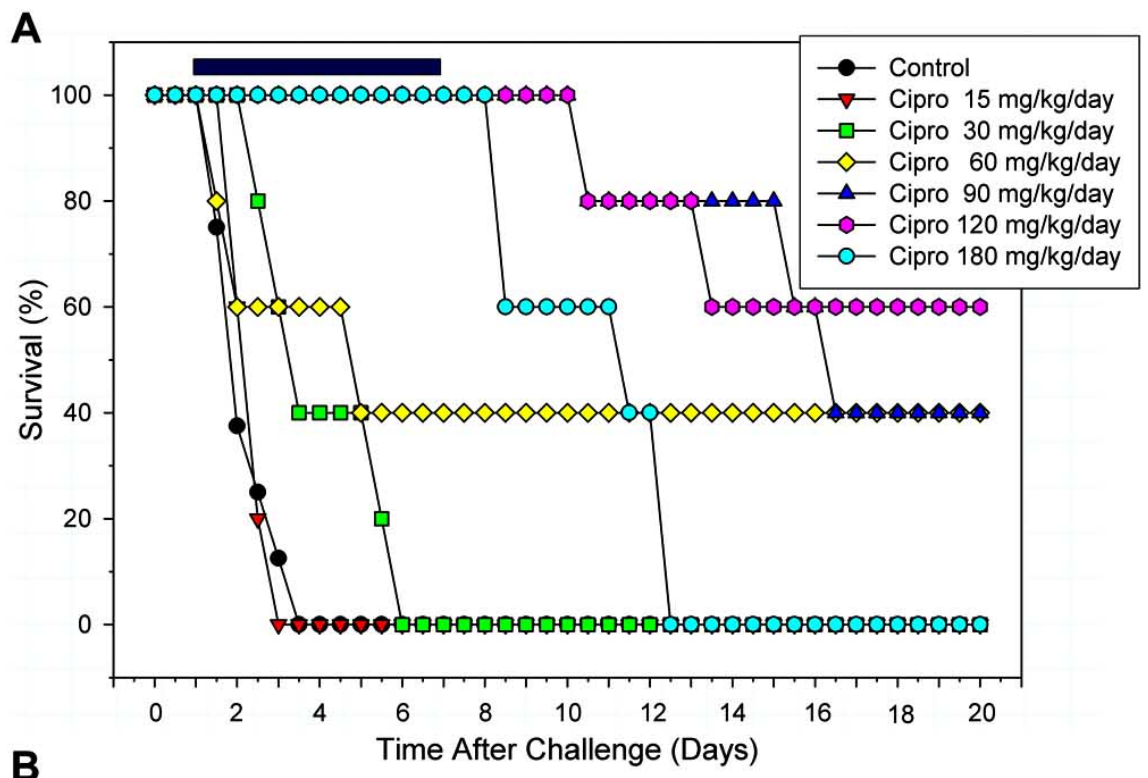

B

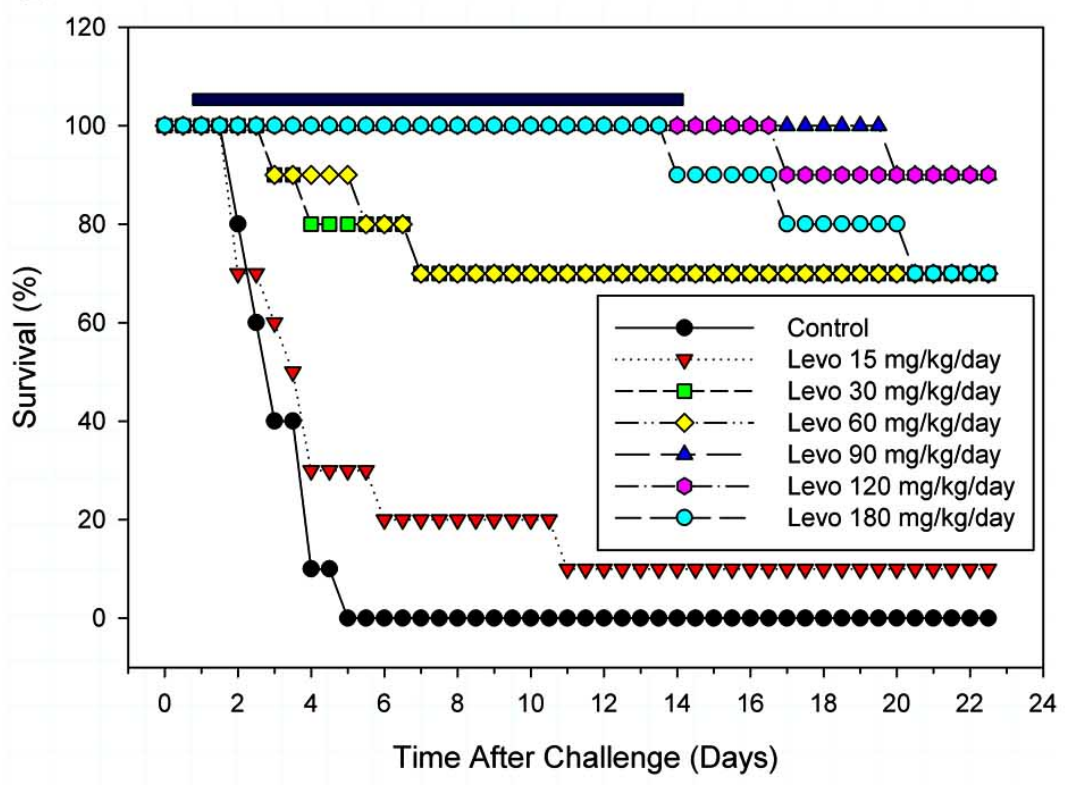

Fig. (1). A. Protection afforded to Swiss-Webster mice by various doses of ciprofloxacin initiated $24 \mathrm{~h}$ after intranasal challenge with 5 LD 50 of $B$. anthracis Ames spores. One-half the daily dose was administered every $12 \mathrm{~h}$. The $\mathrm{LD}_{50}$ dose was previously determined in the nasal instillation model [4]. The horizontal bar indicates the period of ciprofloxacin treatment (6 days). The two highest doses were significant from days 2 through 11.5, while $90 \mathrm{mg} / \mathrm{kg} /$ day was significant from days 2 through 16.5 . Significance for the $60 \mathrm{mg} / \mathrm{kg} / \mathrm{day}$ group was delayed until day 3.5 and only remained so until day 4.5 . Significance at $30 \mathrm{mg} / \mathrm{kg} / \mathrm{day}$ was only at days 2 and 2.5 , while the lowest dose showed no significance. B. Protection afforded to Swiss-Webster mice by various doses of levofloxacin. The daily dose was administered once every 24 $\mathrm{h}$. The horizontal bar indicates the period of levofloxacin treatment (13 days). All groups, except the lowest dose, was significant beginning at day 2 and continued through the end of the study. Significance from the control was determined by the Fisher Exact Test ( $\mathrm{p}<0.05)$. 
ciprofloxacin that were completely protective during shortterm therapy failed to provide long-term survival once treatment ceased. Within the period of treatment, a dose of approximately $70 \mathrm{mg} / \mathrm{kg} /$ day was the $\mathrm{ED}_{50}$ for ciprofloxacin in these mice; however, mouse deaths occurred after antibiotic administration ceased.

During treatment, doses of $90-120 \mathrm{mg} / \mathrm{kg} / \mathrm{day}$ of levofloxacin were completely protective for Swiss-Webster mice challenged with $5 \mathrm{LD}_{50}$ of $B$. anthracis Ames spores (Fig. 1B). Like for ciprofloxacin, some toxicity of the antibiotic was noted at the highest dose of $180 \mathrm{mg} / \mathrm{kg} / \mathrm{day}$. Levofloxacin in doses of $30-60 \mathrm{mg} / \mathrm{kg} /$ day provided approximately $70 \%$ protection, while the lowest dose of 15 $\mathrm{mg} / \mathrm{kg} /$ day of levofloxacin was ineffective. Further, as noted with ciprofloxacin, once treatment with higher doses ceased, mice began to die of anthrax. In this study, we opted to treat animals for 13 days with levofloxacin, although in our subsequent experiments, we reduced the treatment time to 6 days with similar results.

\section{Protection of Hartley Guinea Pigs Against Inhalation Anthrax with Ciprofloxacin and Levofloxacin}

All guinea pigs challenged with $5 \mathrm{LD}_{50}$ of $B$. anthracis Ames spores were completely protected while being injected with doses of ciprofloxacin equal to or greater than 15 $\mathrm{mg} / \mathrm{kg} /$ day; however, deaths began to occur 6 days after the antibiotic treatment ceased (Fig. 2). Identical protection results were observed in other guinea pigs challenged with 25 $\mathrm{LD}_{50}$ of $B$. anthracis spores (data not shown). By titrating the antibiotic dose, we were able to establish a threshold, nonprotective dose $(3.7 \mathrm{mg} / \mathrm{kg} / \mathrm{day})$, which we have used in synergy studies with other treatment modalities [4]. We were unable to establish an $\mathrm{ED}_{50}$ dose of ciprofloxacin in guinea pigs against inhalation anthrax, since regardless of antibiotic dose, all animals eventually succumbed to the infection after treatment ceased; however, during treatment the $\mathrm{ED}_{50}$ was estimated to be $8.8 \mathrm{mg} / \mathrm{kg} / \mathrm{day}$.
Levofloxacin provided $80 \%$ protection to guinea pigs, during sustained treatment with doses $8.5-17 \mathrm{mg} / \mathrm{kg} /$ day against inhalation anthrax; however, the lowest dose of levofloxacin (e.g., $4.2 \mathrm{mg} / \mathrm{kg} /$ day) was ineffective in protecting the animals during treatment. Upon cessation of treatment at 6 days, death of most of the animals ensued even at higher doses of 8.5 and $17 \mathrm{mg} / \mathrm{kg} /$ day (data not shown).

\section{Protection of Dutch-Belted Rabbits Against Inhalation Anthrax with Ciprofloxacin and Levofloxacin}

Fig. (3A) depicts the amount of protection afforded to rabbits against inhalation anthrax using $100 \mathrm{LD}_{50}$ of $B$. anthracis spores when various doses of ciprofloxacin were administered $24 \mathrm{~h}$ post-challenge for 6 days. A $10 \mathrm{mg} / \mathrm{kg} / \mathrm{day}$ dose regimen of ciprofloxacin provided $80 \%$ protection. Unlike the results obtained in similar experiments with mice and guinea pigs, cessation of short-term treatment with ciprofloxacin did not result in increased mortality. The $\mathrm{ED}_{50}$ of ciprofloxacin against inhalation anthrax in the rabbit model was $7.5 \mathrm{mg} / \mathrm{kg} /$ day (Table 3); however, due to the short half-life of the drug, ciprofloxacin was given twice each day.

As shown in Fig. (3B), levofloxacin was equal to or slightly better than ciprofloxacin in protecting rabbits against inhalation anthrax, and the drug could be given once per day. A levofloxacin dose of $\geq 7 \mathrm{mg} / \mathrm{kg}$ /day was completely protective. The $\mathrm{ED}_{50}$ of levofloxacin against anthrax in rabbits was determined to be $4.0 \mathrm{mg} / \mathrm{kg} /$ day (Table 3) when given by the s.c. route. Like for ciprofloxacin, we did not observe further deaths after cessation of the levofloxacin treatment. Fig. (4) shows the effect of delaying treatment with levofloxacin in the rabbit model against inhalation anthrax. In this study, levofloxacin treatment was initiated at various times post challenge and continued for 13 days. Complete protection of the rabbits was achieved during the 13 days of treatment, when initiated $24 \mathrm{~h}$ post challenge, but dropped to $83 \%$ (1 death) after treatment ceased. In comparison, when initiation

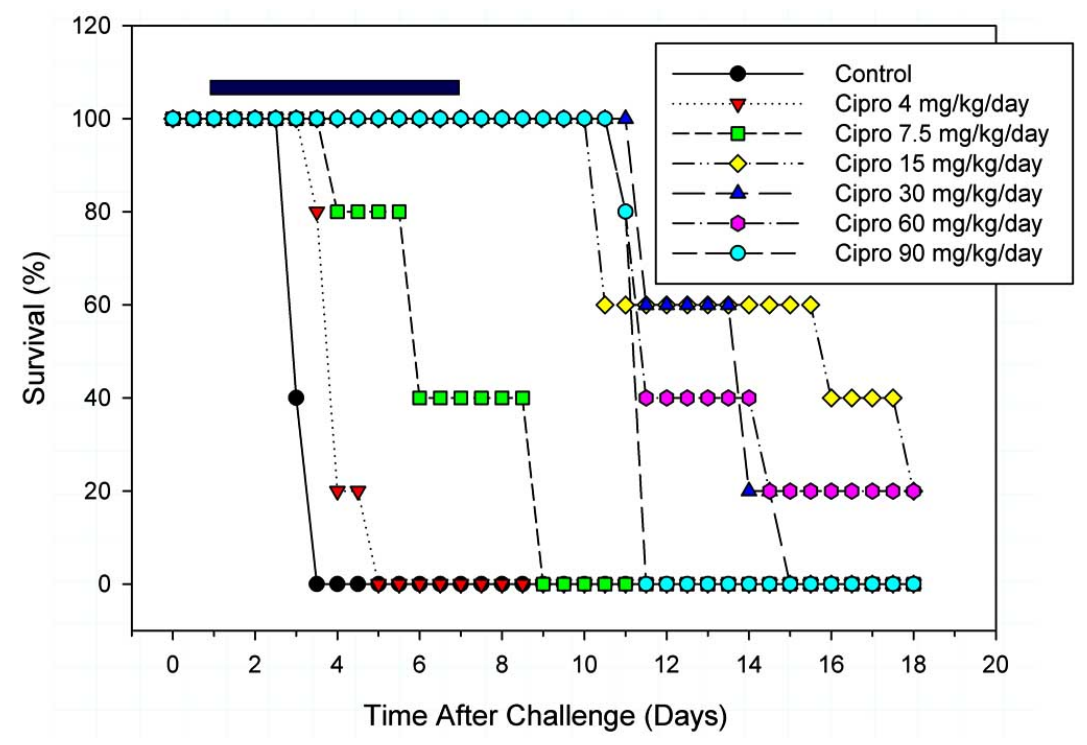

Fig. (2). Survival of Hartley guinea pigs treated with varying doses of ciprofloxacin $24 \mathrm{~h}$ after intranasal challenge with $5 \mathrm{LD}_{50}$ of $B$. anthracis Ames spores. The horizontal bar indicates the period of treatment ( 6 days). The three highest doses were significant from days 3.5 through 11.5. The lower three doses were significant beginning at day 3.5, but ended at day 10 for the $15 \mathrm{mg} / \mathrm{kg} / \mathrm{day}$ group, day 3.5 for the $7.5 \mathrm{mg} / \mathrm{kg} /$ day group, and day 3 for the $4 \mathrm{mg} / \mathrm{kg} /$ day group. Significance from the control was determined by the Fisher Exact Test (p<0.05). 
A
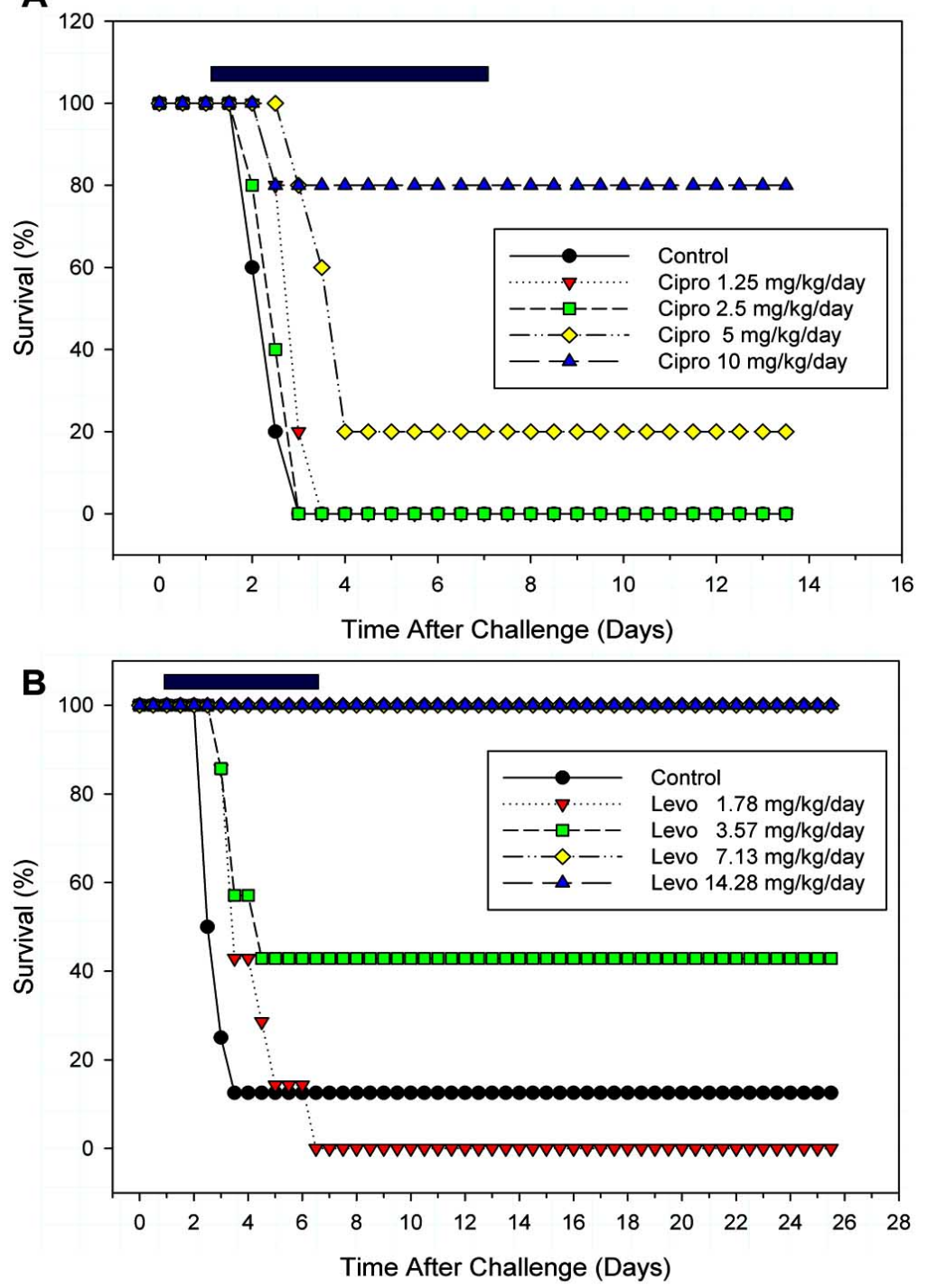

Fig. (3). A. Survival of Dutch-belted rabbits treated with various doses of ciprofloxacin for six days beginning $24 \mathrm{~h}$ after nasal instillation challenge with $100 \mathrm{LD}_{50} \mathrm{~B}$. anthracis Ames spores. The horizontal bar indicates the period of treatment (6 days). The highest dose was significant starting at day 3 and continuing through the end of the study. Significance for the $5 \mathrm{mg} / \mathrm{kg} / \mathrm{day}$ group only lasted for days 2.5 and 3 , while the two lowest doses were not significant. Significance from the control was determined by the Fisher Exact Test (p<0.05). B. Survival of Dutch-belted rabbits treated with various doses of levofloxacin. For all groups, significance $(\mathrm{p}<0.05)$ started on day 2.5 , and while the two highest doses were significant through the end of the study, the $3.57 \mathrm{mg} / \mathrm{kg}$ group was only significant through day 4 , and $1.78 \mathrm{mg} / \mathrm{kg} / \mathrm{day}$, only through day 3 .

of treatment was delayed until $48 \mathrm{~h}$ postinfection, survival dropped to $40 \%$ during treatment and was maintained at this level until the end of the study. Further delay in initiating levofloxacin treatment as late as 57,72 , or $96 \mathrm{~h}$ was completely ineffective in protecting the rabbits. We preferred to treat the animals with levofloxacin for 13 days in this experiment for its protective effects as the antibiotic treatment was delayed after challenge.

\section{Levofloxacin Protects Mice Against Inhalation Exposure to Y.pestis $\mathrm{CO92}$}

Swiss-Webster mice were challenged with $5 \mathrm{LD}_{50}$ of $Y$. pestis, and $24 \mathrm{~h}$ postinfection were injected by the i.p. route with various doses $(0.1-15 \mathrm{mg} / \mathrm{kg} / \mathrm{day})$ of levofloxacin for 6 days. Complete protection of the mice against pneumonic plague was achieved with doses of levofloxacin equal to or greater than $5 \mathrm{mg} / \mathrm{kg} / \mathrm{day}$, and $1 \mathrm{mg} / \mathrm{kg} /$ day yielded $80 \%$ protection. No protection of animals was observed at lower doses of levofloxacin $(0.5$ and $0.1 \mathrm{mg} / \mathrm{kg} /$ day $)$ with $5 \mathrm{LD}_{50}$ of Y. pestis $\mathrm{CO} 92$ (Fig. 5A). The $\mathrm{ED}_{50}$ of levofloxacin for completely protecting mice against pneumonic plague was 0.7 $\mathrm{mg} / \mathrm{kg}$ /day (Table 3).

Even though initiation of the 6 day levofloxacin treatment (5 and $10 \mathrm{mg} / \mathrm{kg} /$ day) was delayed as late as $24 \mathrm{~h}$ postchallenge with $Y$. pestis (Fig. 5B), $100 \%$ of the mice survived; whereas, $90 \%$ survival was observed when treatment with levofloxacin was delayed as late as $36 \mathrm{~h}$. In contrast, a delay in treatment with levofloxacin as late as $48 \mathrm{~h}$ resulted in only $10-20 \%$ survival. 


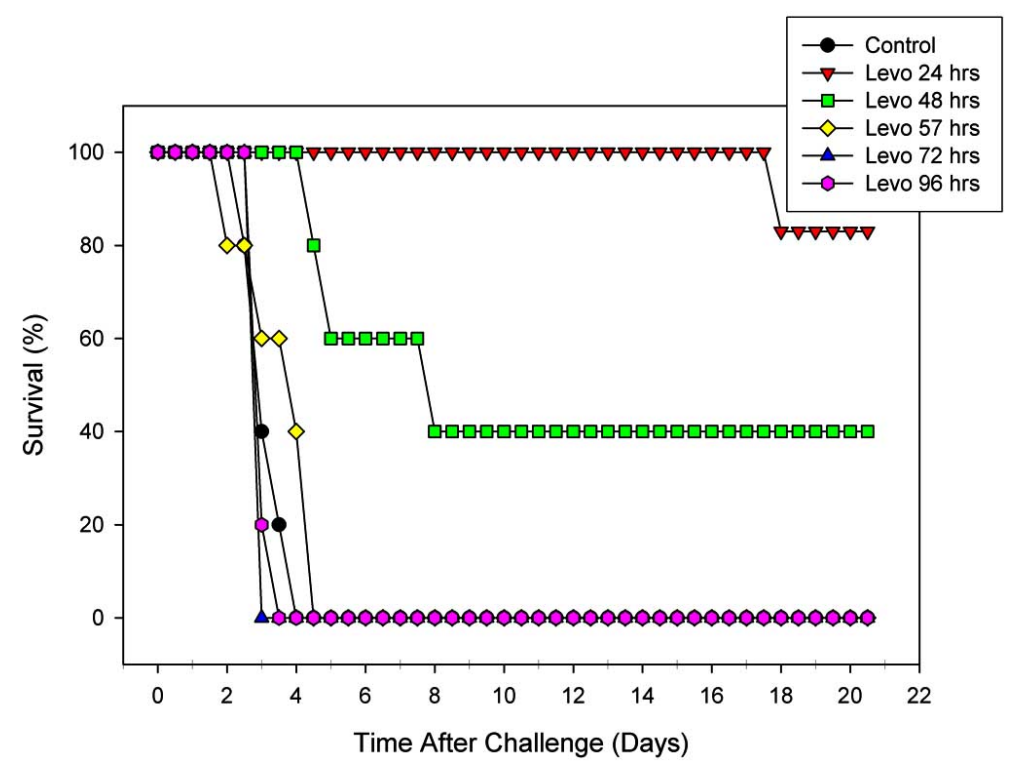

Fig. (4). Survival of Dutch-belted rabbits treated with $14.3 \mathrm{mg} / \mathrm{kg} /$ day of levofloxacin beginning at various times after challenge with 100 $\mathrm{LD}_{50}$ B. anthracis Ames spores by nasal instillation. Levofloxacin was given for 13 days following the challenge of each group. Groups that initiated treatment at 24 and $48 \mathrm{~h}$, were significant beginning at day 3, however, the $48 \mathrm{~h}$ group was only significant until day 7 , while the 24 $\mathrm{h}$ group was significant through the end of the study. All other groups were not significant. Significance from the control was determined by the Fisher Exact Test $(\mathrm{p}<0.05)$.

\section{Levofloxacin Protects Mice Against Inhalation Exposure to F. tularensis SCHU S4}

Fig. (6A) shows that 13 days of levofloxacin treatment, initiated $24 \mathrm{~h}$ post-challenge, in concentrations (0.5-10 $\mathrm{mg} / \mathrm{kg} /$ day) completely protected the mice against tularemia during treatment. After treatment with levofloxacin at 1 $\mathrm{mg} / \mathrm{kg}$ /day ceased, a death occurred. At the lowest dose of $0.1 \mathrm{mg} / \mathrm{kg} /$ day, animals succumbed to infection during the antibiotic treatment, which progressively increased to $50 \%$ survival (Table 3) after cessation of antibiotic therapy. We preferred 13 days of antibiotic treatment as $F$. tularenesis is an intracellular pathogen, and we suspected that longer treatment might be required for observing protection.

Fig. (6B) illustrates that initiation of levofloxacin treatment $(40 \mathrm{mg} / \mathrm{kg} /$ day) for 13 days in mice infected with $F$. tularensis could be delayed as long as $72 \mathrm{~h}$ postchallenge and still achieve $100 \%$ protection. Even when levofloxacin treatment was delayed as late as $96 \mathrm{~h}, 80 \%$ of the mice survived; however, delay until $120 \mathrm{~h}$ resulted in no protection.

\section{Pharmacokinetics and $\mathbf{E D}_{50} / \mathbf{E D}_{100}$ of Ciprofloxacin and Levofloxacin}

Table 2 lists the pharmacokinetic parameters of ciprofloxacin and levofloxacin for each of the three models based on $\mathrm{ED}_{100}$ dosing. Within each animal species, the $\mathrm{C}_{\max }$, AUCs, elimination $T_{1 / 2}$, and TBC values were remarkably similar between the two fluoroquinolones, despite the slightly higher milligram per kilogram dose required for ciprofloxacin to achieve the same efficacy in the guinea pig and rabbit models. The only significantly different parameters included higher peak serum concentrations of levofloxacin compared to ciprofloxacin $(45.2 \pm 10.3 \mu \mathrm{g} / \mathrm{ml}$ vs. $25.5 \pm$ $10.3 \mu \mathrm{g} / \mathrm{ml}, \mathrm{P}<0.001)$ in mice receiving the same $90 \mathrm{mg} / \mathrm{kg}$ dose and a longer $T_{1 / 2}$ of levofloxacin versus ciprofloxacin in the rabbit model $(2.8 \pm 1.2 \mathrm{~h}$ vs $1.5 \pm 0.7 \mathrm{~h}, \mathrm{P}=0.009)$. The mean elimination half lives of both agents ranged from 1.4 to 2.8 hours in all three species.

Table 3 shows a summary of the antibiotic dose protection data providing $\mathrm{ED}_{50}$ and $\mathrm{ED}_{100}$ values against inhalation anthrax in the three different animal models. The $\mathrm{ED}_{50}$ values for ciprofloxacin and levofloxacin against inhalation anthrax in Swiss-Webster mice were 70 and $28 \mathrm{mg} / \mathrm{kg} / \mathrm{day}$, respectively. When ciprofloxacin and levofloxacin were tested against anthrax in the guinea pig model, the $\mathrm{ED}_{50}$ values were 8.8 and $5.0 \mathrm{mg} / \mathrm{kg} /$ day, respectively. Similarly, we determined that the $\mathrm{ED}_{50} \mathrm{~s}$ of ciprofloxacin and levofloxacin against anthrax using rabbits were 7.5 and $4.0 \mathrm{mg} / \mathrm{kg} / \mathrm{day}$, respectively. The $\mathrm{ED}_{50}$ values for levofloxacin in mice infected with $Y$. pestis and $F$. tularensis were 0.7 and 0.1 , respectively (Table 3 ).

\section{DISCUSSION}

The infectivity profile (Table 1) of the three bacterial pathogens revealed that $F$. tularensis SCHU S4 and $Y$. pestis CO92 had lower $\mathrm{LD}_{50}$ 's than $B$. anthracis Ames, when the agents were administered by nasal instillation. In related experiments (in mice), the virulence of all three select agents, when administered by subcutaneous injection, was essentially the same, that is, approximately 5-6 cells/spores per animal (data not shown). With a low $\mathrm{LD}_{50}$ nasal instillation dose of 33 cells in BALB/c mice, F. tularensis barely exceeded the infectivity of $Y$. pestis, which was 100 cells. In Swiss-Webster mice, the $\mathrm{LD}_{50} \mathrm{~s}$ of these two pathogens were about two logs lower than that of B. anthracis Ames spores. The $\mathrm{LD}_{50}$ 's for $B$. anthracis Ames spores by nasal instillation in guinea pigs and rabbits were approximately 1 log greater than that for mice. Importantly, the $\mathrm{LD}_{50}$ of $B$. anthracis Ames spores by aerosolization to Dutch-belted rabbits was determined earlier to be $1 \times 10^{5} \mathrm{cfu}$, which was the same as the nasal instillation dose $[4,56]$. 

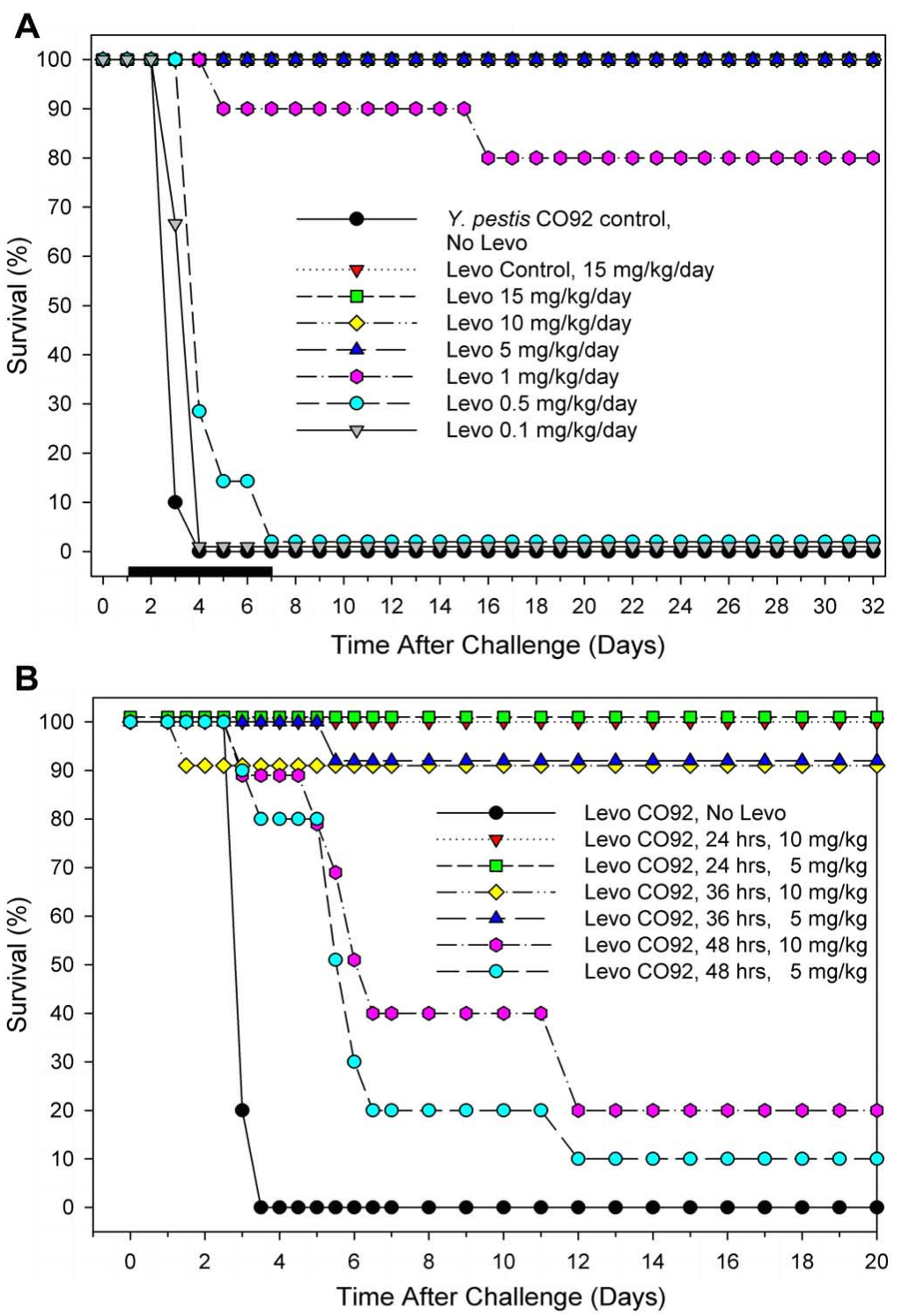

Fig. (5). A. Survival of Swiss-Webster mice treated with various doses of levofloxacin for six days starting 24 h after challenge with 5 LD ${ }_{50}$ of $Y$. pestis $\mathrm{C} 092$ cells by nasal instillation. The horizontal bar indicates the period of levofloxacin treatment. Complete protection against primary challenge was achieved by a dose of $5 \mathrm{mg} / \mathrm{kg} /$ day levofloxacin. Significance for all groups began at day 3 , and while the two lowest doses were only significant for this time point, all other groups were significant until day 32. Significance from the control was determined by the Fisher Exact Test $(\mathrm{p}<0.05)$. B. Survival of Swiss-Webster mice challenged with $Y$. pestis C092 followed treatment with 5 or 10 $\mathrm{mg} / \mathrm{kg} /$ day of Levofloxacin at various times post challenge. Animals were dosed for 6 days, once initiated, and survival was compared to the control group (no levofloxacin). Significance $(\mathrm{p}<0.05)$ for all treatment groups from the control group began at day 3 . Both doses of levofloxacin at 24 and $36 \mathrm{~h}$ postchallenge were significantly different $(\mathrm{p}<0.05)$ from the control group until the end of the study, but at $48 \mathrm{~h}$ both 5 and $10 \mathrm{mg} / \mathrm{kg}$ groups were not significantly different from the control group $(\mathrm{p}>0.05)$.

It was interesting to note in the mouse models that the $\mathrm{ED}_{50}$ for levofloxacin against $B$. anthracis was approximately 40 -fold higher than the $\mathrm{ED}_{50}$ for $Y$. pestis $\left(\mathrm{ED}_{50}=0.7\right)$. Similar results were observed with levofloxacin against $B$. anthracis and $F$. tularensis in $\mathrm{BALB} / \mathrm{c}$ mice $\left(\mathrm{ED}_{50}=0.1\right)$. We suspect that the basis for these observed differences in $\mathrm{ED}_{50} \mathrm{~S}$ is multifactorial and could be related to the number of bacteria constituting the challenge dose $\left(5 \mathrm{LD}_{50}\right)$, rather than to the potency of levofloxacin against Gram-negative versus Gram-positive bacteria. Alternatively, the resistance of spores to antibiotics and chemicals and/or the presence of capsule around $B$. anthracis vegetative cells could have affected the antibiotic dose or exposure needed to reduce the bacterial load. In fact, the MICs with levofloxacin and ciprofloxacin for B. anthracis Ames and Y. pestis CO92 were each determined to be $0.03 \mu \mathrm{g} / \mathrm{ml}$, while for $F$. tularensis it was $0.03 \mu \mathrm{g} / \mathrm{ml}$ with levofloxacin and $0.01 \mu \mathrm{g} / \mathrm{ml}$ with ciprofloxacin. In addition, a recent study examining the spore subpopulations suggested suppression of resistance required greater drug exposure with more frequent antibiotic dosing [57].

It is also plausible that, differences between the three organisms with respect to $\mathrm{ED}_{50} / \mathrm{ED}_{100}$ doses of the two quinolones may be illustrating variations in the immune response related to the various virulence factors and the 

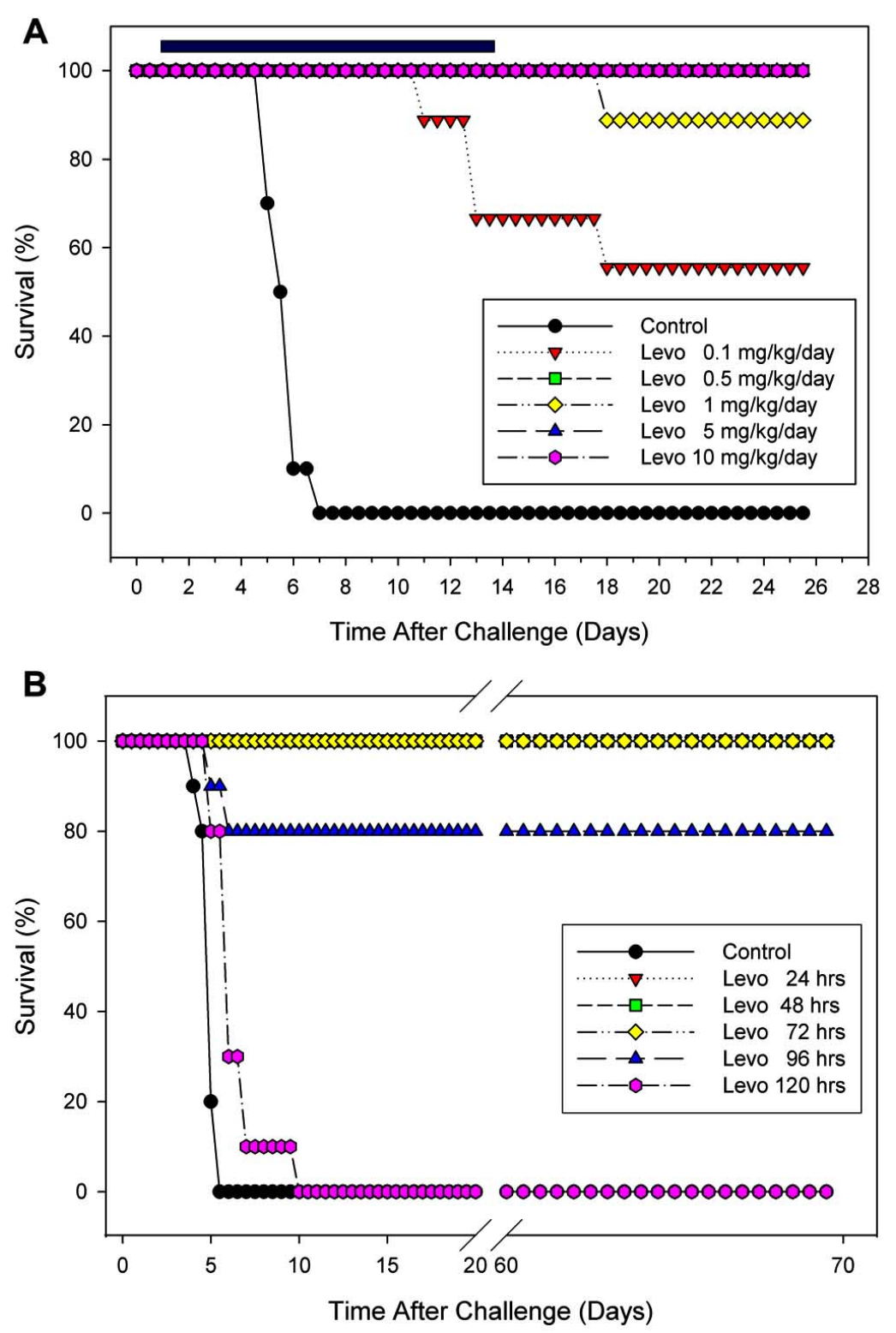

Fig. (6). A. Survival of BALB/c mice challenged with $3 \mathrm{LD}_{50} F$. tularensis SCHU S4 by nasal instillation followed by treatment with various doses of levofloxacin. The horizontal bar indicates the period of treatment (13 days). Significance from the control was determined by the Fisher Exact Test $(\mathrm{p}<0.05)$, and all of the groups of mice except for the $0.1 \mathrm{mg} / \mathrm{kg} / \mathrm{day}$ dose of levofloxacin were significant. B. Survival of BALB/c mice challenged with $F$. tularensis SCHU S4 followed by treatment with $40 \mathrm{mg} / \mathrm{kg} / \mathrm{day}$ starting at various times post challenge. The period of treatment was 13 days. Significance from the control was determined by the Fisher Exact Test $(\mathrm{p}<0.05)$ and all of the groups of mice, except for the one to which antibiotic treatment, was administered $120 \mathrm{~h}$ postinfection, were significant.

known immunomodulatory properties of ciprofloxacin and levofloxacin [42]. For example, the down-regulation of LPSmediated proinflammatory cytokine production associated with fluoroquinolone administration may, in part, explain why lower effective doses are needed for infection with endotoxin-producing $F$. tularensis and $Y$. pestis, as compared to infection with $B$. anthracis. Clearly, further study of the indirect effect of fluoroquinolones on the immune response following infection with these pathogens is needed to address this speculation.

Our results illustrated that levofloxacin is an effective antibiotic in protecting experimental animals against all three bacterial infections; however, the fluoroquinolones appeared more potent in their in vivo bactericidal effect against pneumonic plague and tularemia, than against inhalation anthrax.

The serum concentrations and pharmacokinetic parameters of ciprofloxacin and levofloxacin were nearly identical in the guinea pig and rabbit models despite the slightly higher $\mathrm{ED}_{100}$ dosage of ciprofloxacin required to obtain the same effectiveness in the survival studies. Therefore, with respect to these two models, there appears to be concordance between $\mathrm{ED}_{50} / \mathrm{ED}_{100}$ doses, fluoroquinolone concentrations and a desirable therapeutic effect. In addition, the serum concentrations and the derived kinetic parameters are consistent with the published literature $[40,47,58,59]$. The noted limitation of these concentration data is the fact they were obtained in uninfected animals and involved single-dose 
Table 2. Summary of Pharmacokinetic Data in Three Animal Species Dosed with Ciprofloxacin or Levofloxacin

\begin{tabular}{|c|c|c|c|c|c|c|}
\hline Regimen (Drug-mg/kg-Route) & $\mathrm{C}_{\max }(\mu \mathrm{g} / \mathrm{ml})$ & $\mathbf{T}_{\max }(\mathbf{h})$ & $\operatorname{AUC}_{0-6 h}(\mu \mathrm{g} \cdot \mathbf{h} / \mathrm{ml})$ & $\mathrm{AUC}_{\mathbf{0}-\infty \mathbf{h}}(\boldsymbol{\mu g} \cdot \mathbf{h} / \mathrm{ml})$ & $\mathbf{T}_{1 / 2}(\mathbf{h})$ & $\mathrm{TBC}(\mathrm{ml} / \mathrm{min})$ \\
\hline \multicolumn{7}{|l|}{ Swiss-Webster Mice } \\
\hline Cip-90-ip & $25.5 \pm 4.5 @$ & 0.25 & 56.5 & 62.1 & 1.8 & 0.80 \\
\hline Lev-5-ip & $13.4 \pm 6.3$ & 0.25 & 14.6 & 16.7 & 2.1 & 0.17 \\
\hline Lev-90-ip & 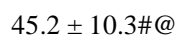 & 0.25 & 36.2 & 37.4 & 1.7 & 1.33 \\
\hline \multicolumn{7}{|l|}{ Hartley Guinea Pigs } \\
\hline Cip-15-sc & $2.2 \pm 1.0$ & $1.0(0.25-1.5)$ & $5.0 \pm 0.6$ & $5.5 \pm 0.7$ & $1.4 \pm 0.2$ & $18.0 \pm 2.4$ \\
\hline Lev-8.5-sc & $2.7 \pm 2.1$ & $1.0(0.25-1.5)$ & $3.8 \pm 0.9$ & $6.6 \pm 3.3$ & $1.7 \pm 0.6$ & $10.5 \pm 4.2$ \\
\hline \multicolumn{7}{|l|}{ Dutch-Belted Rabbits } \\
\hline Cip-10-im & $2.3 \pm 1.5$ & $0.63(0.25-2)$ & $3.2 \pm 0.5$ & $5.3 \pm 1.9$ & $1.5 \pm 0.7$ & $32.9 \pm 11.7$ \\
\hline Lev-7.1-im & $1.2 \pm 0.2$ & $1.25(1-1.5)$ & $3.3 \pm 0.5$ & $5.1 \pm 1.7$ & $2.8 \pm 1.2 *$ & $31.3 \pm 10.1$ \\
\hline
\end{tabular}

Data given as mean \pm S.D except $T_{\max }$ given as median (range); *P=0.009, Lev-7.1 vs Cip-10; \#P=0.013, Lev-90 vs Cip-90;@ P=<0.001, Cip-90 and Lev-90 vs Lev-5.

Note: composite nature of most PK parameters in mice prevents statistical analysis.

AUC $=$ Area Under Curve (Total drug exposure over time course).

$\mathrm{TBC}=$ Total Body Clearance.

Table 3. Summary of In Vivo $\mathrm{ED}_{50}$ and $\mathrm{ED}_{100}$ Values During Treatment with Fluoroquinolones Against B. anthracis, Y. pestis, and F. tularensis Following Challenge by Nasal Instillation

$\mathrm{ED}_{50}(\mathrm{mg} / \mathrm{kg} / \mathrm{day}) / \mathrm{ED}_{100}(\mathrm{mg} / \mathrm{kg} / \mathrm{day})$

\begin{tabular}{|l|l|l|l|l|}
\hline \multirow{2}{*}{ Animal } & Antibiotic & B. anthracis Ames Spores & Y. pestis CO92 Cells & F.tularensis SCHU S4 Cells \\
\hline \hline \multirow{2}{*}{ Swiss-Webster Mice } & Ciprofloxacin & $70 / 90$ & N.D. & N.D. \\
\cline { 2 - 5 } & Levofloxacin & $28 / 90$ & $0.7 / 5.0$ & $0.1 / 5.0$ \\
\hline \multirow{3}{*}{ Hartley Guinea Pig } & Ciprofloxacin & $8.8 / 15$ & N.D. & N.D. \\
\cline { 2 - 5 } & Levofloxacin & $5.0 / 17$ & N.D. & N.D. \\
\hline \multirow{2}{*}{ Dutch-belted Rabbit } & Ciprofloxacin & $7.5 / 10$ & N.D. & N.D. \\
\cline { 2 - 5 } & Levofloxacin & $4.0 / 7.0$ & N.D. & N.D. \\
\hline
\end{tabular}

administration. The approximate $\mathrm{C}_{\max } / \mathrm{MIC}$ ratios for ciprofloxacin and levofloxacin in guinea pigs and rabbits were 70 and 40-80, respectively. The corresponding AUC/MIC ratios were approximately $150-175$ and $160-200$. These values are well above the $\mathrm{C}_{\max } / \mathrm{MIC}$ ratio of 19.6-33.8 (rhesus monkeys) and AUC/MIC ratio of $15.8-30$ (murine) that have been associated with bacterial eradication and clinical outcomes reported from recent pharmacodynamic experiments specifically involving infection with B. anthracis [23, 37, 40-41]. Deziel et al. [37] reported AUC/MIC ratios of approximately 200-300 were needed for effective therapy; however, outcome was highly dependent on the animal model used and frequency of dose administration. Finally, the $\mathrm{C}_{\max } / \mathrm{MIC}$ and $\mathrm{AUC} / \mathrm{MIC}$ ratios determined from data in the present study may have been even higher in infected animals with diminished hepatic and renal elimination receiving multiple-dose administration [58].

The extremely high $90 \mathrm{mg} / \mathrm{kg}$ dose of both ciprofloxacin and levofloxacin required for $100 \%$ efficacy against $B$. anthracis in mice resulted in roughly dose-dependent increases in $\mathrm{C}_{\max }$ and $\mathrm{AUC}$ parameters. These values correspond to $\mathrm{C}_{\max } / \mathrm{MIC}$ and AUC/MIC ratios of 800 to nearly 1900. Therefore, the observed differences between animal species with regard to $B$. anthracis infection are not readily explained on the basis of achievable serum concentrations relative to the MIC; however, it has been suggested that other pharmacodynamic parameters such as time above the MIC (T>MIC) may be an important determinant of outcome for the metabolically inactive spore population that may germinate at antibiotic concentrations at or below the MIC [37, 40, 57]. In addition, this disparity among models may be related to species-specific immune response interactions to the virulence factors associated with $B$. anthracis.

Regardless, the $\mathrm{ED}_{100}$ for ciprofloxacin in rabbits given by the i.m. route was $10 \mathrm{mg} / \mathrm{kg} /$ day for anthrax. In human adults, the recommended dose for ciprofloxacin for inhalational anthrax by the oral route is $400-500 \mathrm{mg}$ (5.7-7.1 mg/kg for an average $70 \mathrm{~kg}$ body weight) every $12 \mathrm{~h}$ for 60 days. For the highest oral dose, the equivalent injectable (i.v.) dose of ciprofloxacin is $400 \mathrm{mg}$ every $12 \mathrm{~h}$ 
(http://www.globalrph.com/ciprofloxacin_dilution.htm.). Likewise, the recommended levofloxacin dose for adult human use is $500 \mathrm{mg} / \mathrm{day}(7.1 \mathrm{mg} / \mathrm{kg} /$ day $)$, and the $\mathrm{ED}_{100}$ in rabbits for levofloxacin is $7 \mathrm{mg} / \mathrm{kg} /$ day. These $\mathrm{ED}_{100}$ doses of ciprofloxacin and levofloxacin in rabbits seem comparable to human doses; however, these data should be interpreted very cautiously as several body physiological functions play key roles in determining antibiotic concentrations effective in a patient.

In mouse and guinea pig models, it was clear that shortterm therapy with either ciprofloxacin or levofloxacin was not capable of providing long term protection against $B$. anthracis, since cessation of antibiotic treatment resulted in deaths of the animals. The basis for this observation presumably is due to the inability of the antibiotic to kill all the spores. However, long-term protection from antibiotics in rabbits appeared superior. Whether this could be related to differences in spore germination in rodents versus rabbits is not known. Asynchronous or delayed germination is believed to be an important problem in patients that has caused physicians to prescribe long-term courses of antibiotic treatment (e.g., 60 days or longer). This medical strategy was based upon the report that the majority of nonhuman primates, challenged with aerosols of $B$. anthracis spores, were protected against anthrax infection when treated for 60 days; however, superior protection was conferred by administering a combination of ciprofloxacin and vaccination with protective antigen (PA) [60]. It is also possible that the fluoroquinolones exert differential immunomodulatory effects on the innate immune responses of rodents versus rabbits. Indeed our own studies have also indicated a synergistic protective effect in mice and guinea pigs against anthrax when ciprofloxacin was combined with monoclonal antibodies against protective antigen (PA) of B. anthracis [4].

Despite the effectiveness of the fluoroquinolones in treating inhalation anthrax, as demonstrated in these animal models, resistance to fluoroquinolones is emerging among other bacteria that cause clinical infections [61-63]. It is also important to consider the possibility of bacteria acquiring resistance to a particular antibiotic during treatment. Further, physicians must have other effective antibiotics to prescribe in the event of a bioterrorism attack involving a $B$. anthracis strain or other bacterial threat agents carrying multiple antibiotic resistance factors. This scenario is of particular concern because additional time is required to ascertain the antibiotic susceptibility profile of the bacteria, and the models indicate that prompt initiation of appropriate antibiotic therapy postexposure is essential to prevent a lethal infection with any of these select agents.

Treatment with levofloxacin, is also very effective against plague and tularemia and a 6-13 day treatment $24 \mathrm{~h}$ post infection resulted in $100 \%$ protection. Therefore, levofloxacin could be a drug of choice for all of the three category A select bacterial agents. Recently, antibioticresistant strains of $Y$. pestis emerged that were isolated from human cases of bubonic plague in Madagascar [64, 65]. These plague isolates with natural resistance to antibiotics contained transmissible plasmids; in one case, the plasmid possessed multi-drug resistant determinants for chloramphenicol acetyltransferase, streptomycin-modifying enzyme and TEM-1 beta-lactamase; and in the other case, the plas- mid encoded high-level resistance to streptomycin. The bioweapon programs of the Former Soviet Union engineered drug-resistant variants of highly pathogenic $B$. anthracis strains specific for at least 10 different antibiotics (including the fluoroquinolones) [66]. Similarly, spontaneous-resistant mutants of $B$. anthracis Sterne have been isolated that were resistant to 18 different antibiotics [67]. The same could be true for $Y$. pestis and $F$. tularensis. Therefore, studies should continue to develop new therapeutics and antibiotics against these deadly pathogens, as currently there are no vaccines for plague and tularemia. Further, although Biothrax vaccine (Emergent Biosolutions, Gaithersburg, MD) is available for anthrax, it provides short-term protection and requires multiple injections.

\section{ACKNOWLEDGMENTS}

The authors would like to thank Judy Hewitt, Kristin DeBord, Tracy MacGill, and Anthony Macaluso of the NIAID for advice on experimental design and analysis during the progression of these studies. We acknowledge the financial support from NIAID contract \#N01-AI-30065, NIAID grant U01 AI5385802, and Army grant DAMD170210699. The superb administrative management and quest for quality laboratory operation by Laurie Sower had a positive impact on our research program. The authors are also grateful for the technical assistance of Kristin Walberg and for her tireless quest for GLP compliance. Additional technical support was provided by staff members of Drs. Chopra, Klimpel, and Eaves-Pyles' laboratories at UTMB.

\section{AUTHORS' CONTRIBUTIONS}

JP designed experiments and directed the animal studies with $B$. anthracis and drafted the manuscript. DH suggested and performed the quantification of fluoroquinolones in serum samples, as well as contributed to manuscript preparation. SM, JP, JH, JMT, WL, CP, BC, and BG performed all BSL-3 animal experiments with inhalation anthrax and edited the manuscript. SF, SA, and JS performed the animal experiments with pneumonic plague. MK, JT, and TE performed the animal experiments with pneumonic tularemia. GK, TE, and AC designed experiments and directed the animal experiments with $F$. tularensis and $Y$. pestis, as well as contributed to manuscript preparation.

\section{REFERENCES}

[1] Sawada-Hirai R, Jiang I, Wang F, et al. Human anti-anthrax protective antigen neutralizing monoclonal antibodies derived from donors vaccinated with anthrax vaccine adsorbed. J Immune Based Ther Vaccines 2004; 2: 1-5.

[2] Cui X, Li Y, Moayeri M, Choi GH, et al. Late treatment with a protective antigen-directed monoclonal antibody improves hemodynamic function and survival in a lethal toxin-infused rat model of anthrax sepsis. J Infect Dis 2005; 191: 422-34.

[3] Wang F, Ruther P, Jiang I, et al. Human monoclonal antibodies that neutralize anthrax toxin by inhibiting heptamer assembly. Hum Antibodies 2004; 13: 105-110.

[4] Peterson JW, Comer JE, Noffsinger DM, et al. Human monoclonal anti-protective antigen antibody completely protects rabbits and is synergistic with ciprofloxacin in protecting mice and guinea pigs against inhalation anthrax. Infect Immun 2006; 74: 1016-24.

[5] Vitale L, Blanset D, Lowy I, et al. Prophylaxis and therapy of inhalational anthrax by a novel monoclonal antibody to protective antigen that mimics vaccine-induced immunity. Infect Immun 2006; 74: 5840-7. 
[6] Sanchez AM, Thomas D, Gillespie EJ, et al. Amiodarone and bepridil inhibit anthrax toxin entry into host cells. Antimicrob Agents Chemother 2007; 51: 2403-11.

[7] Comer JE, Noffsinger DM, McHenry DJ, et al. Evaluation of the protective effects of quinacrine against Bacillus anthracis Ames. J Toxicol Environ Health A 2006; 69: 1083-95.

[8] Johnson SL, Chen LH, Pellecchia M. A high-throughput screening approach to anthrax lethal factor inhibition. Bioorg Chem 2007; 35 : 306-12.

[9] Hepler RW, Kelly R, McNeely TB, et al. A recombinant 63-kDa form of Bacillus anthracis protective antigen produced in the yeast Saccharomyces cerevisiae provides protection in rabbit and primate inhalational challenge models of anthrax infection. Vaccine 2006; 24: $1501-14$

[10] Gupta M, Alam S, Bhatnagar R. Catalytically inactive anthrax toxin(s) are potential prophylactic agents. Vaccine 2007; 25: 84109.

[11] Klinman DM, Xie H, Ivins BE. CpG oligonucleotides improve the protective immune response induced by the licensed anthrax vaccine. Ann N Y Acad Sci 2006; 1082: 137-50.

[12] Russell P, Eley SM, Green M, et al. Efficacy of doxycycline and ciprofloxacin against experimental Yersinia pestis infection. J Antimicrob Chemother 1998; 41: 301-305.

[13] Enderlin G, Morales L, Jacobs RF, Cross JT. Streptomycin and alternative agents for the treatment of tularemia: review of the literature. Clin Infect Dis 1994; 19: 42-7.

[14] Byrne WR, Welkos SL, Pitt ML, et al. Antibiotic treatment of experimental pneumonic plague in mice. Antimicrob Agents Chemother 1998; 42: 675-81.

[15] Inglesby TV, Dennis DT, Henderson DA, et al. Plague as a biological weapon: medical and public health management. Working Group on Civilian Biodefense. JAMA 2000; 283: 228190.

[16] Williamson ED, Flick-Smith HC, Waters E, et al. Immunogenicity of the $\mathrm{rF} 1+\mathrm{rV}$ vaccine for plague with identification of potential immune correlates. Microb Pathog 2007; 42: 11-21.

[17] Williamson ED. Plague vaccine research and development. J Appl Microbiol 2001; 91: 606-8.

[18] Conlan JW. Vaccines against Francisella tularensis--past, present and future. Expert Rev Vaccines 2004; 3: 307-14.

[19] Amsden GW: Mandell, Douglas, and Bennett's Principles and Practice of Infectious Diseases $6^{\text {th }}$ ed. Livingstone: Philadelphia, Elsevier Churchill 2005; vol. 1.

[20] Ambrose PG, Bhavnani SM, Owens RC, Jr. Clinical pharmacodynamics of quinolones. Infect Dis Clin North Am 2003; 17: 52943.

[21] Craig WA. Pharmacokinetic/pharmacodynamic parameters: rationale for antibacterial dosing of mice and men. Clin Infect Dis 1998; 26: 1-10; quiz 1-2.

[22] Andes D, Craig WA. Animal model pharmacokinetics and pharmacodynamics: a critical review. Int J Antimicrob Agents 2002; 19: 261-8.

[23] Ambrose PG, Forrest A, Craig WA, et al. Pharmacokineticspharmacodynamics of gatifloxacin in a lethal murine Bacillus anthracis inhalation infection model. Antimicrob Agents Chemother 2007; 51: 4351-5.

[24] Lyons CR, Lovchik J, Hutt J, et al. Murine model of pulmonary anthrax: kinetics of dissemination, histopathology, and mouse strain susceptibility. Infect Immun 2004; 72: 4801-9.

[25] Steward J, Lever MS, Simpson AJ, Sefton AM, Brooks TJ. Postexposure prophylaxis of systemic anthrax in mice and treatment with fluoroquinolones. J Antimicrob Chemother 2004; 54: 95-9.

[26] Russell P, Eley SM, Bell DL, Manchee RJ, Titball RW. Doxycycline or ciprofloxacin prophylaxis and therapy against experimental Yersinia pestis infection in mice. $\mathrm{J}$ Antimicrob Chemother 1996; 37: 769-74.

[27] Louie A, Deziel MR, Liu W, Drusano GL. Impact of resistance selection and mutant growth fitness on the relative efficacies of streptomycin and levofloxacin for plague therapy. Antimicrob Agents Chemother 2007; 51: 2661-2667.

[28] Steward J, Lever MS, Russell P, et al. Efficacy of the latest fluoroquinolones against experimental Yersinia pestis. Int $\mathrm{J}$ Antimicrob Agents 2004; 24: 609-12.

[29] Russell P, Eley SM, Fulop MJ, Bell DL, Titball RW. The efficacy of ciprofloxacin and doxycycline against experimental tularaemia. J Antimicrob Chemother 1998; 41: 461-5.
[30] Piercy T, Steward J, Lever MS, Brooks TJ. In vivo efficacy of fluoroquinolones against systemic tularaemia infection in mice. $\mathrm{J}$ Antimicrob Chemother 2005; 56: 1069-73.

[31] Steward J, Piercy T, Lever MS, Simpson AJ. Treatment of murine pneumonic Francisella tularensis infection with gatifloxacin, moxifloxacin or ciprofloxacin. Int J Antimicrob Agents 2006; 27: 439-43.

[32] Drusano GL, Okusanya OO, Okusanya A, et al. Is 60 days of ciprofloxacin administration necessary for postexposure prophylaxis for Bacillus anthracis? Antimicrob Agents Chemother 2008; 52: 3973-9.

[33] Louie A, Heine HS, Kim K, et al. Use of an in vitro pharmacodynamic model to derive a linezolid regimen that optimizes bacterial kill and prevents emergence of resistance in Bacillus anthracis. Antimicrob Agents Chemother 2008; 52: 2486-96.

[34] Friedlander AM, Welkos SL, Pitt ML, et al. Postexposure prophylaxis against experimental inhalation anthrax. J Infect Dis 1993; 167: 1239-43.

[35] Vietri NJ, Purcell BK, Tobery SA, et al. A short course of antibiotic treatment is effective in preventing death from experimental inhalational anthrax after discontinuing antibiotics. J Infect Dis 2009; 199: 336-41.

[36] Kao LM, Bush K, Barnewall R, et al. Pharmacokinetic considerations and efficacy of levofloxacin in an inhalational anthrax (postexposure) rhesus monkey model. Antimicrob Agents Chemother 2006; 50: 3535-42.

[37] Deziel MR, Heine H, Louie A, et al. Effective antimicrobial regimens for use in humans for therapy of Bacillus anthracis infections and postexposure prophylaxis. Antimicrob Agents Chemother 2005; 49: 5099-5106.

[38] Altboum Z, Gozes Y, Barnea A, Pass A, White M, Kobiler D. Postexposure prophylaxis against anthrax: evaluation of various treatment regimens in intranasally infected guinea pigs. Infect Immun 2002; 70: 6231-41.

[39] Shoop WL, Xiong Y, Wiltsie J, et al. Anthrax lethal factor inhibition. Proc Natl Acad Sci USA 2005; 102: 7958-63.

[40] Heine HS, Bassett J, Miller L, et al. Determination of antibiotic efficacy against Bacillus anthracis in a mouse aerosol challenge model. Antimicrob Agents Chemother 2007; 51: 1373-9.

[41] Kihira T, Sato J, Shibata T. Pharmacokinetic-pharmacodynamic analysis of fluoroquinolones against Bacillus anthracis. J Infect Chemother 2004; 10: 97-100.

[42] Dalhoff A, Shalit I. Immunomodulatory effects of quinolones. Lancet Infect Dis 2003; 3: 359-71.

[43] Khan AA, Slifer TR, Araujo FG, Suzuki Y, Remington JS Protection against lipopolysaccharide-induced death by fluoroquinolones. Antimicrob Agents Chemother 2000; 44: 3169-73.

[44] Purswani MU, Eckert SJ, Arora HK, Noel GJ. Effect of ciprofloxacin on lethal and sublethal challenge with endotoxin and on early cytokine responses in a murine in vivo model. $\mathrm{J}$ Antimicrob Chemother 2002; 50: 51-8.

[45] Shalit I, Kletter Y, Halperin D, et al. Immunomodulatory effects of moxifloxacin in comparison to ciprofloxacin and G-CSF in a murine model of cyclophosphamide-induced leukopenia. Eur J Haematol 2001; 66: 287-96.

[46] Zehavi-Willner T, Shalit I. Enhancement of interleukin-2 production in human lymphocytes by two new quinolone derivatives. Lymphokine Res 1989; 8: 35-46.

[47] Scaglione F, Mouton JW, Mattina R, Fraschini F. Pharmacodynamics of levofloxacin and ciprofloxacin in a murine pneumonia model: peak concentration/MIC versus area under the curve/MIC ratios. Antimicrob Agents Chemother 2003; 47: 2749-55.

[48] Leighton TJ, Doi RH. The stability of messenger ribonucleic acid during sporulation in Bacillus subtilis. J Biol Chem 1971; 246: 3189-95.

[49] Hamouda T, Shih AY, Baker JR. A rapid staining technique for the detection of the initiation of germination of bacterial spores. Lett Appl Microbiol 2002; 34: 86-90.

[50] Agar SL, Sha J, Foltz SM, et al. Characterization of a mouse model of plague after aerosolization of Yersinia pestis CO92. Microbiology 2008; 154: 1939-48.

[51] Sha J, Agar SL, Baze WB, et al. Braun lipoprotein (Lpp) contributes to virulence of yersiniae: potential role of $\mathrm{Lpp}$ in inducing bubonic and pneumonic plague. Infect Immun 2008; 76: 1390-409. 
[52] Gentry M, Taormina J, Pyles RB, et al. Role of primary human alveolar epithelial cells in host defense against Francisella tularensis infection. Infect Immun 2007; 75: 3969-78.

[53] Liang H, Kays MB, Sowinski KM. Separation of levofloxacin, ciprofloxacin, gatifloxacin, moxifloxacin, trovafloxacin and cinoxacin by high-performance liquid chromatography: application to levofloxacin determination in human plasma. J Chromatogr B Analyt Technol Biomed Life Sci 2002; 772: 53-63.

[54] Healy DP, Holland EJ, Nordlund ML, et al. Concentrations of levofloxacin, ofloxacin, and ciprofloxacin in human corneal stromal tissue and aqueous humor after topical administration. Cornea 2003; 23: 255-63.

[55] Gibaldi M, Perrier D. Pharmacokinetics $2^{\text {nd }}$ ed. New York, NY, Marcell Dekker, Inc 1982.

[56] Peterson JW, Comer JE, Baze WB, et al. Human monoclonal antibody AVP-21D9 to protective antigen reduces dissemination of the Bacillus anthracis Ames strain from the lungs in a rabbit model. Infect Immun 2007; 75: 3414-24.

[57] Drusano GL, Okusanya OO, Okusanya AO, et al. Impact of spore biology on the rate of kill and suppression of resistance in Bacillus anthracis. Antimicrob Agents Chemother 2009; 53: 4718-25.

[58] Fernandez J, Barrett JF, Licata L, Amaratunga D, Frosco M. Comparison of efficacies of oral levofloxacin and oral ciprofloxacin in a rabbit model of a staphylococcal abscess. Antimicrob Agents Chemother 1999; 43: 667-71.

[59] Onyeji CO, Bui KQ, Owens RC, Jr., Nicolau DP, Quintiliani R, Nightingale $\mathrm{CH}$. Comparative efficacies of levofloxacin and ciprofloxacin against Streptococcus pneumoniae in a mouse model of experimental septicaemia. Int J Antimicrob Agents 1999; 12: $107-14$.
[60] Vietri NJ, Purcell BK, Lawler JV, et al. Short-course postexposure antibiotic prophylaxis combined with vaccination protects against experimental inhalational anthrax. Proc Natl Acad Sci USA 2006; 103: 7813-6.

[61] Eguchi H, Kuwahara $\mathrm{T}$, Miyamoto $\mathrm{T}$, et al. High-level fluoroquinolone resistance in ophthalmic clinical isolates belonging to the species Corynebacterium macginleyi. J Clin Microbiol 2008; 46: 527-32.

[62] Razavi B, Apisarnthanarak A, Mundy LM. Clostridium difficile: emergence of hypervirulence and fluoroquinolone resistance. Infection 2007; 35: 300-7.

[63] Zemkova M, Kotlarova J, Merka V, Cermak P, Vlcek J, Jebavy L. Emergence of fluoroquinolone resistance in Escherichia coli isolates at the department of clinical hematology. New Microbiol 2007; 30: 423-30.

[64] Galimand M, Guiyoule A, Gerbaud G, et al. Multidrug resistance in Yersinia pestis mediated by a transferable plasmid. N Engl J Med 1997; 337: 677-80.

[65] Guiyoule A, Gerbaud G, Buchrieser C, et al. Transferable plasmidmediated resistance to streptomycin in a clinical isolate of Yersinia pestis. Emerg Infect Dis 2001; 7: 43-8.

[66] Alibek K. Combating Terrorism: Assessing the threat of a biological weapons attack. Testimony before a special congressional committee hearing. In: Congressional committee. Oct 22, 2001 edn: Newsmax.com; 2001.

[67] Athamna A, Athamna M, Abu-Rashed N, Medlej B, Bast DJ, Rubinstein E. Selection of Bacillus anthracis isolates resistant to antibiotics. J Antimicrob Chemother 2004; 54: 424-8. 